\title{
EZH2 Protein Expression and Tumor Response to Neoadjuvant Chemotherapy in Locally Advanced Breast Cancer
}

\section{Expressão da proteína EZH2 e resposta tumoral à quimioterapia neoadjuvante no câncer de mama localmente avançado}

Lucienne Pereira Del Grossi Neusquen, $\mathrm{MSc}^{1}$ José Roberto Filassi, $\mathrm{PhD}^{1}$ Carlos Elias Fristachi, $\mathrm{PhD}^{2}$ Kátia Candido Carvalho, $\mathrm{PhD}^{3}$ Maíra Teixeira Dória, $\mathrm{MD}^{1}$ José Maria Soares Júnior, $\mathrm{PhD}^{1,3}$ José Roberto Morales Piato, $\mathrm{PhD}^{1}$

${ }^{1}$ Department of Obstetrics and Gynecology, Universidade de São Paulo, São Paulo, São Paulo, Brazil

2 Instituto Arnaldo Vieira de Carvalho, São Paulo, São Paulo, Brazil ${ }^{3}$ Laboratory of Structural and Molecular Gynecology (LIM-58), Faculdade de Medicina da Universidade de São Paulo, São Paulo, São Paulo, Brazil
Address for correspondence Maíra Teixeira Dória, MD, Department of Obstetrics and Gynecology, Universidade de São Paulo, Av. Dr. Enéas de Carvalho Aguiar, 255, $10^{\circ}$ andar, Cerqueira Cesar, 05403000, São Paulo, Brazil (e-mail: maira_doria@yahoo.com.br).

Rev Bras Ginecol Obstet 2016;38:280-286.

\begin{abstract}
Keywords

- EZH2

- breast neoplasms

- tumor markers

- neoadjuvant therapy

- gene expression

Introduction Neoadjuvant chemotherapy (NAC) is the standard treatment for locally advanced breast cancer. However, some tumors will not respond to this treatment due to histological and molecular features. The protein EZH2 (enhancer of zest homolog 2) is a histone methyltransferase that is correlated with poorly differentiated breast carcinomas and aggressive tumor behavior.

Purpose The present study evaluated the association between EZH2 expression and response to NAC, and its correlation with HER2 overexpression, estrogen and progesterone receptors (ER, PR) and Ki-67 proliferation index.

Methods A total of 60 patients with locally advanced breast cancer treated with NAC were selected for this study. Twenty-three paraffin blocks had not enough material for tissue resection, and were not evaluated. A tissue microarray based in immunohistochemistry $(\mathrm{IHC})$ analysis of $\mathrm{EZH} 2$ was performed for the remaining 37 specimens. Patients were divided into two groups based on response to NAC.

Results EZH2 expression was significantly associated with markers of poor prognosis such as ER negativity $(p=0.001)$, PR negativity $(p=0.042)$ and high $\mathrm{K}_{\mathrm{i}}-67$ proliferation index $(p=0.002)$. High EZH2 expression was not correlated with the response to NAC.
\end{abstract}

received January 23, 2016 accepted May 18, 2016
DOI http://dx.doi.org/ 10.1055/s-0036-1584954. ISSN 0100-7203.
Copyright $\odot 2016$ by Thieme Publicações License terms Ltda, Rio de Janeiro, Brazil

(c) $(1) \$$ 


\section{Resumo}

\author{
Palavras-chave \\ - EZH2 \\ - neoplasias da mama \\ - marcadores \\ tumorais \\ - terapia \\ neoadjuvante \\ - expressão gênica
}

Conclusions Our data suggested that EZH2 protein expression may not correlate with the clinical response to NAC. Other studies with more patients are needed to confirm this observation.

Introdução A quimioterapia neoadjuvante é o tratamento padrão para os cânceres de mama localmente avançados. Entretanto, apenas uma porcentagem desses tumores irá responder ao tratamento, devido a características histológicas e moleculares. A proteína EZH2 (enhancer of zest homolog 2) é uma histona metiltransferase associada a tumores mal diferenciados e de comportamento agressivo.

Objetivo $\mathrm{O}$ presente estudo teve como objetivo avaliar a associação entre a expressão da proteína EZH2 e a resposta à quimioterapia neoadjuvante, além da correlação dessa proteína com hiper-expressão de HER2, receptores de estrogênio e progesterona, e o marcador de proliferação Ki-67.

Métodos Um total de 60 pacientes com câncer de mama localmente avançado tratadas com quimioterapia neoadjuvante foram selecionadas para esse estudo. Vinte e três blocos de parafina não continham material suficiente para ressecção e não foram avaliados. Foi realizado microarray baseado em análise imuno-histoquímica da proteína EZH2 para as 36 pacientes restantes. As pacientes foram divididas em dois grupos baseado na resposta à quimioterapia neoadjuvante.

Resultados A expressão da proteína EZH2 foi significativamente associada com marcadores de pior prognóstico, como negatividade para receptor de estrogênio $(p=0,001)$ e progesterona $(p=0,042)$, além de alto $\mathrm{K}_{\mathrm{i}}-67(p=0,002)$. Entretanto, a alta expressão da $\mathrm{EZH2}$ não se correlacionou com a resposta à quimioterapia neoadjuvante.

Conclusões Nossos dados sugerem que a expressão da proteína EZH2 pode não estar relacionada com a resposta clínica à quimioterapia neoadjuvante. Outros estudos com maior número de pacientes são necessários para confirmar esses achados.

\section{Introduction}

Neoadjuvant chemotherapy (NAC) is the standard of care for patients with locally advanced breast cancer. ${ }^{1-6}$ It provides local control and reduction in tumor size, increasing breastpreserving rates. Neoadjuvant treatment also provides an opportunity to test tumor sensitivity to chemotherapy in vivo. Approximately $15 \%$ of patients will achieve a complete response to NAC, whereas another $15 \%$ will display minimal changes or a progressive disease. ${ }^{7}$ Patients who achieve a pathologically complete response (pCR) after NAC have better disease-free survival and overall survival rates. ${ }^{8}$ The identification of tumor markers that predict response to therapy, distinguishing responders from non-responders, can improve therapeutic decisions.

Clinical and pathological features considered to be predictors of disease progression with NAC include negative expression of estrogen receptor (ER) and progesterone receptor (PR), high score of $\mathrm{K}_{\mathrm{i}}-67$, and high nuclear grade of tumor cells. ${ }^{7}$ These markers have also been associated with a complete pathologic response to neoadjuvant chemotherapy, suggesting that although morphologically similar, highly proliferative tumors can be divided into two subpopulations, namely those that are highly sensitive and those that are highly resistant to chemotherapeutics. ${ }^{9}$ There remains a need for the discovery of new molecular markers that can differentiate these subpopulations of highly proliferative tumors.

The protein EZH2 (enhancer of zest homolog 2) encodes a histone methyltransferase, which is the catalytic core protein of the polycomb repressor complex 2 (PCR2).$^{10} \mathrm{PCR} 2$ are epigenetic chromatin modifiers that regulate transcription through nucleosome modification, chromatin remodeling, and interaction with other transcription factors. ${ }^{11}$ These proteins are involved in cell regulation and cell division, and are well known for initiating target gene silencing by promoting H3K27me3 trimethylation, which is catalyzed by EZH2. ${ }^{12}$ Several studies showed that the EZH2 and the signal transducer and activator of transcription 3 (STAT3) are involved in the proliferation, self-renewal and pluripotency of cancer stem cells. ${ }^{13}$

Overexpression of EZH2 has been described in prostate, breast, bladder, gastric, lung and ovarian cancers. ${ }^{10}$ In breast cancer, elevated EZH2 expression has been correlated with poorly differentiated tumors and aggressive tumor behavior. ${ }^{14-17}$ Holm et $\mathrm{al}^{18}$ tested the EZH2 and H3K27me3 abundance in more than 400 tumors using immunohistochemistry (IHC). They found significantly high expression of EZH2 in triple-negative, basal-like and HER2-enriched tumors, and high H3K27me3 in luminal A, HER2-enriched and normal-like tumors. ${ }^{18}$ Therefore, high abundance of EZH2 was associated with poor distant free-survival. 
EZH2 is also overexpressed in inflammatory breast cancer (IBC), the most metastatic variant of breast cancer with the poorest survival. ${ }^{11,19,20}$ An analysis of 88 tissue microarrays from IBC demonstrated that EZH2 is highly expressed in $75.7 \%$ of them, and was associated significantly with unfavorable prognostic factors, such as higher tumor grade and triple-negative status. ${ }^{11}$

To date, there are no studies in the literature evaluating if there is a clear correlation between EZH2 protein expression and the response of breast cancer tumors to NAC. Therefore, the aim of this study was to determine if EZH2 protein expression can predict tumor response to NAC in locally advanced breast cancers. One predefined secondary aim of this study was to evaluate the association of EZH2 expression and other pathological features, such as ER and PR expression, $\mathrm{K}_{\mathrm{i}}-67$ proliferation index and HER2 overexpression.

\section{Materials and Methods}

\section{Patient Selection}

This was a case-control pilot study developed at Faculdade de Medicina da Universidade de São Paulo with the analysis of breast cancer patients treated at Instituto de Oncologia e Mastologia Arnaldo Vieira de Carvalho. Primary tumor specimens with local advanced breast cancer (stage IIB or IIIA) from 60 patients were selected. The patients received antracycline-based neoadjuvant chemotherapy, and were treated at Instituto de Oncologia e Mastologia Arnaldo Vieira de Carvalho. The tumor samples were obtained in accordance with protocols approved by the Institutional Ethics Committee at the Instituto de Oncologia Arnaldo Vieira de Carvalho and at Faculdade de Medicina da Universidade de São Paulo. Exclusion criteria were bilateral disease and pregnancy concomitant with the diagnosis of breast cancer.

\section{Pathological Assessment}

After analysis of the tumor specimens, 23 paraffin blocks had not enough material for tissue resection, and were not evaluated. Thirty-seven paraffin-embedded tumor specimen blocks were selected for this study and cut into 5 - $\mu \mathrm{m}$ slices prior to being stained with hematoxylin and eosin. The morphologically representative areas (only tumor cells, no necrosis or normal breast cells) were defined as the site for replicate core extraction from the master block.

Tissue microarrays were constructed from these tumor samples, and IHC was performed for EZH2 (clone NCL - LEXH2, 1:200 dilution, Novocastra) and the usual prognostic markers: ER (clone SP1; 1: 200 dilution, Neomark); PR (clone pgR636, 1: 600 dilution, DAKO); HER-2 (1: 400 dilution, Spring); and $\mathrm{K}_{\mathrm{i}}-67$ (clone MIB-1, 1: 4800 dilution, DAKO).

\section{Evaluation of Staining Results}

The expression of the EZH2 protein was based on the IHC labeling in accordance with Allred's criteria, which are commonly used for the evaluation of hormone receptor expression (-Fig. 1). Thus, the observed intensity of cellular staining was classified as negative, weak, intermediate, or intense. The percentage of stained cells was assigned a proportion score as follows: $0 \%$; $>0$ and $<1 \%$; $1-10 \%$; $11-33 \%$; $34-66 \%$; and $>67 \%$ cells positively labeled. The intensity scores (range, $0-3$ ) and proportional scores (range, 1-5) were summed, resulting in a total score between 0 and 8 to enable comparison with other biomarkers (-Table $\mathbf{1}$ ).

\section{Assessment of Clinical Response}

Clinical assessment of tumor response was performed before initiating NAC and pre-operatively using calipers (Sanny Professional Skinfold caliper, Ann Arbor, USA). The response criteria set forth by the International Union for Cancer Control (UICC) were employed. ${ }^{21}$ According to clinical response, patients were divided into two groups: Group 1 (the responders) consisted of patients who achieved $\geq 50 \%$ reduction in tumor size; and Group 2 (the non-responders) consisted of patients in whom the aforementioned objective response was not observed.

For data analysis, patients were grouped according to the UICC response criteria: the responder group included
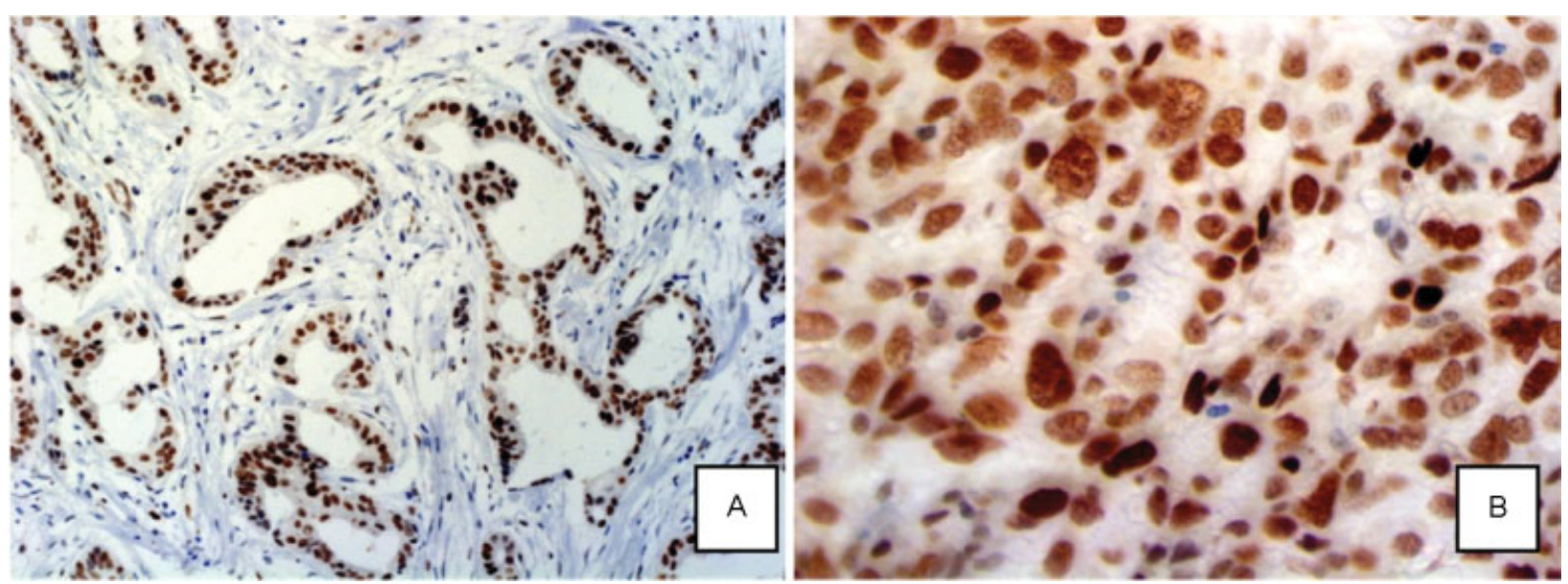

Fig. 1 Photomicrograph of EZH2 + cells. (A) Photomicrograph of well-differentiated invasive ductal breast carcinoma tumor with EZH2+ cells (200x magnification). (B) Photomicrograph of invasive ductal breast carcinoma with EZH2+ cells (630x magnification). Project B-18. 
Table 1 The evaluation of EZH2 protein expression on the tumor tissue

\begin{tabular}{|l|l|l|l|}
\hline $\begin{array}{l}\text { Staining } \\
\text { intensity }\end{array}$ & $\begin{array}{l}\text { Intensity } \\
\text { score }\end{array}$ & $\begin{array}{l}\text { Percentage } \\
\text { of labeled cells }\end{array}$ & Score \\
\hline Negative & 0 & $0 \%$ (None) & 0 \\
\hline Weak & 1 & $>0$ and $<1 \%$ & 1 \\
\hline Intermediate & 2 & $1-10 \%$ & 2 \\
\hline Intense & 3 & $11-33 \%$ & 3 \\
\hline & & $34-66 \%$ & 4 \\
\hline & & $>67 \%$ & 5 \\
\hline
\end{tabular}

patients with complete or partial clinical response to NAC, and the non-responder group included patients who had no change in tumor size or disease progression.

\section{Statistical Analysis}

Statistical analysis was performed using a linear correlation analysis by Spearman's test for non-parametric correlations. The means and distributions of the quantitative variables of both groups were determined with the Student's t-test or the Mann-Whitney test for non-parametric data, when appropriate. Fisher's exact test was performed to compare the proportions. Mean values are presented with standard deviations (SDs) in the results. Statistical significance was determined as $p<0.05$ with a two-sided test.

\section{Results}

A reduction of $50 \%$ or more in tumor size was achieved in 19 of 37 cases (51.3\%) - Group 1. The other 18 cases were classified as non-responders (Group 2). The pathological characteristics of Group 1 are summarized in - Table 2, and - Table 3 presents the data from Group 2. The mean age was $46 \pm 11$ years for responders and $56 \pm 11$ years for non-responders $(p=0.008)$. It was not possible to perform IHC for $\mathrm{K}_{\mathrm{i}}-67$ proliferation index in 6 tumor specimens, EZH2 expression in 5, HER2 in 1, ER status in 2, and PR status in 1 specimen.

Of all tumor specimens evaluated for EZH2, the lowest amount of expression was $11 \%$. The majority of patients (62.5\%) had more than $66 \%$ of cells positive for EZH2 (-Table 4).

To evaluate the association between EZH2 expression and the other pathological factors, EZH2 expression was divided into two categories according to percentage of cells positive for EZH2: $34-66 \%$ and $\geq 67 \%$. High EZH2 expression was significantly associated with markers of poor prognosis, such as ER negativity ( $p=0.001)$, PR negativity $(p=0.042)$, and

Table 2 Pathological characteristics of Group 1

\begin{tabular}{|c|c|c|c|c|c|c|c|c|}
\hline Patient & Histology & HG & $\mathrm{ER}^{*}$ & $\mathrm{PR}^{*}$ & HER2† & p53 & $K_{i}-67(\%)$ & $\mathrm{EZH} 2 \ddagger$ \\
\hline 1 & IDC & 2 & 7 & 7 & 0 & negative & 40 & 8 \\
\hline 2 & IDC & 3 & 0 & 0 & 0 & negative & 90 & 8 \\
\hline 3 & IDC & 2 & 8 & 8 & 0 & negative & 10 & 6 \\
\hline 4 & IDC & 3 & 0 & 0 & 0 & positive & 50 & 7 \\
\hline 5 & IDC & 2 & 6 & 8 & 3 & negative & 60 & 8 \\
\hline 6 & IDC & 2 & 8 & 8 & 1 & negative & 50 & 7 \\
\hline 7 & IDC & 1 & 5 & 7 & 0 & negative & 5 & 5 \\
\hline 8 & IDC & 2 & 7 & 5 & 0 & positive & 30 & 7 \\
\hline 9 & IDC & 2 & 7 & 4 & 0 & negative & 60 & 7 \\
\hline 10 & IDC & 3 & 0 & 0 & 0 & negative & 90 & 8 \\
\hline 11 & IDC & 3 & 0 & 0 & 0 & positive & 90 & 8 \\
\hline 12 & IDC & 3 & 0 & 0 & 0 & positive & 80 & 8 \\
\hline 13 & ILC & 1 & 6 & 7 & 0 & negative & 30 & 7 \\
\hline 14 & IDC & 1 & 6 & 7 & 1 & negative & $\mathrm{NA}$ & 8 \\
\hline 15 & IDC & 2 & 0 & 0 & 0 & negative & 40 & 8 \\
\hline 16 & IDC & 2 & 6 & 8 & 3 & negative & 35 & 7 \\
\hline 17 & IDC & 1 & 7 & 5 & 0 & negative & 25 & 7 \\
\hline 18 & IDC & 3 & 6 & 3 & 0 & negative & NA & NA \\
\hline 19 & IDC & 2 & 4 & 6 & 2 & positive & NA & NA \\
\hline
\end{tabular}

Abbreviations: ER, estrogen receptor; IDC, invasive ductal carcinoma; ILC, invasive lobular carcinoma; HG, histological grade; NA, not available; p53, protein $\mathrm{P53}$; PR, progesterone receptor.

*Allred score for ER and PR; †HER2: 0 and 1, negative; 2, undetermined; 3, positive; †Score for EZH2 as presented in - Table 1. 
Table 3 Pathological characteristics of Group 2

\begin{tabular}{|l|l|l|l|l|l|l|l|l|}
\hline Patient & Histology & HC & ER $^{*}$ & PR $^{*}$ & HER2 & p53 & $\mathrm{K}_{\mathrm{i}}-67(\%)$ & EZH2 \\
\hline 20 & IDC & 3 & 0 & 0 & 0 & positive & 10 & 8 \\
\hline 21 & IDC & 2 & 5 & 8 & 0 & negative & 75 & 8 \\
\hline 22 & IDC & 3 & NA & NA & 3 & negative & 39 & 8 \\
\hline 23 & IDC & 3 & 0 & 0 & 2 & positive & 74 & 8 \\
\hline 24 & IDC & 3 & 0 & 0 & 3 & positive & NA & NA \\
\hline 25 & IDC & 2 & 8 & 7 & 0 & negative & 8 & 7 \\
\hline 26 & IDC & 2 & 3 & 5 & 0 & negative & 11 & 8 \\
\hline 27 & IDC & 3 & 0 & 0 & 0 & positive & 70 & 8 \\
\hline 28 & IDC & 2 & 7 & 7 & 0 & negative & 60 & 8 \\
\hline 29 & IDC & 3 & 0 & 0 & 3 & positive & 80 & 8 \\
\hline 30 & IDC & 2 & 6 & 5 & 3 & negative & 80 & 8 \\
\hline 31 & IDC & 2 & 6 & 0 & 0 & negative & 30 & 7 \\
\hline 32 & IDC & 2 & 5 & 3 & 0 & negative & 12 & 6 \\
\hline 33 & IDC & 1 & NA & 0 & NA & negative & NA & NA \\
\hline 34 & IDC & 1 & 8 & 7 & 0 & negative & 5 & 7 \\
\hline 35 & IDC & 1 & 6 & 6 & 0 & negative & 30 & 8 \\
\hline 36 & IDC & 3 & 0 & 0 & 0 & negative & 95 & 8 \\
\hline 37 & IDC & 2 & 8 & 8 & 0 & negative & NA & NA \\
\hline
\end{tabular}

Abbreviations: ER, estrogen receptor; IDC, invasive ductal carcinoma; ILC, invasive lobular carcinoma; HG, histological grade; NA, not available; p53, protein $\mathrm{P53}$; PR, progesterone receptor.

*Allred score for ER and PR; †HER2: 0 and 1, negative; 2, undetermined; 3, positive; †Score for EZH2 as presented in - Table 1.

high $\mathrm{K}_{\mathrm{i}}-67$ proliferation index $(p=0.002)$. There was no association between EZH2 expression and either age or HER2 status.

To assess if there was an association between EZH2 expression and response to NAC, we also divided patients into the two categories of EZH2 expression (34-66\% and $\geq 67 \%$ ). As reported in - Table 5 , our analysis revealed no association between responder status and EZH2 protein expression $(p=0.135)$.

\section{Discussion}

The heterogeneity of breast cancers in their evolution and response to standard treatments compels us to identify markers that allow individualized therapies. Despite the improvement in breast cancer treatment in the last decades, there is still a significant percentage of patients that do not

Table 4 Percentage of EZH2+ cells in all specimens analyzed

\begin{tabular}{|l|l|c|}
\hline EZH2 (\%) & No. of patients & $\%$ \\
\hline $11-33 \%$ & 1 & 3.1 \\
\hline $34-66 \%$ & 11 & 34.4 \\
\hline$\geq 67 \%$ & 20 & 62.5 \\
\hline TOTAL & 32 & 100 \\
\hline
\end{tabular}

respond to therapy. Antibody targeted immunotherapy for HER2 protein represented an important step toward tailored treatment for patients who express that protein. The discovery of other antigen targets is a great challenge, and will allow the development of novel therapeutic strategies for breast cancer. ${ }^{8,22-24}$ Our study focused on EZH2 protein expression and its correlation with the response to neoadjuvant chemotherapy.

In our study, all of the tumors analyzed were positive for EZH2 protein expression in at least $11 \%$ of invasive tumor cells. This finding is in accordance with a previous report from Bachmann et al, which shows EZH2 expression in locally advanced breast tumors. ${ }^{15}$ The variability of EZH2 protein expression detected by IHC allowed us to classify EZH2 presence by the percentage of cells stained and the intensity of staining, producing a composite score ranging from 0 to 8 . This score allowed the data to be compared with other parameters that had a history of being evaluated in this manner, such as ER and PR statuses.

Our findings regarding the association between EZH2 protein expression and HER2 and $\mathrm{K}_{\mathrm{i}}-67$ proteins expression was significantly positive for the correlation between EZH2 and $\mathrm{K}_{\mathrm{i}}-67$ expression, while the association between EZH2 and HER2 did not reach statistical significance. This correlation between EZH2 and $\mathrm{K}_{\mathrm{i}}-67$ is consistent with prior publications. ${ }^{15,25,26}$ The potential association between EZH2 and HER2 remains controversial. Collett et $\mathrm{al}^{25}$ and Holm et al ${ }^{18}$ 
Table 5 Percentage of EZH2 + cells and response to chemotherapy among samples with $\geq 11 \%$ EZH $2+$ cells

\begin{tabular}{|l|l|l|l|l|l|l|l|}
\hline \multirow{2}{*}{ EZH2 (\%) } & \multicolumn{3}{|l|}{ Responders } & \multicolumn{2}{l|}{ Non-responders } & \multicolumn{2}{l|}{ Total } \\
\cline { 2 - 7 } & $\mathbf{n}$ & $\%$ & $\mathbf{n}$ & $\%$ & $\mathbf{N}$ & $\%$ & \\
\hline $34-66 \%$ & 8 & 50.0 & 3 & 20.0 & 11 & 34.4 & \\
\hline$\geq 67 \%$ & 8 & 50.0 & 12 & 80.0 & 20 & 62.5 & 0.135 \\
\hline TOTAL & 16 & 100.0 & 15 & 100.0 & 31 & 100.0 & \\
\hline
\end{tabular}

Abbreviation: $\mathrm{n}$, number of patients.

*Fisher's exact test.

found high abundance of EZH2 in HER2-enriched tumors, whereas our data and Kleer et $\mathrm{al}^{27}$ did not demonstrate this association. Our study also demonstrated an association between EZH2 high expression and negativity for ER and $\mathrm{PR}$, which are also markers of poor prognosis.

Interestingly, high EZH2 expression was not correlated with the response to NAC. These results may suggest that $\mathrm{EZH} 2$ is a marker for aggressive subtypes of breast cancer, but not a predictor of response to NAC. However, these findings may be due to the small number of specimens analyzed, not reflecting the real predictive value of EZH2.

The current study has limitations that include the small number of cases analyzed, which is prone to selection bias. The loss of some cases, either due to loss of tissue cores during processing, or due to lack of material, might constitute another limitation. Nonetheless, the strength of our study was the evaluation of a series of breast cancers from a single institution, analyzing EZH2 expression, $\mathrm{K}_{\mathrm{i}}-67$ proliferation index, HER2 overexpression, ER and PR statuses, all by immunohistochemistry. To the best of our knowledge, this is the first study to evaluate the association of EZH2 and the response to neoadjuvant chemotherapy.

Chemo resistance is the principal obstacle in successful therapy for patients with breast cancer. Evidences suggest that EZH2 may regulate cancer stem/initiating cell equilibrium in advanced breast cancer. ${ }^{19}$ Therefore, EZH2 expression might be useful not only as a marker of poor prognosis, but also as a target for new therapies. Mu et al demonstrated that the EZH2 knockdown significantly suppressed tumor growth in vivo in a new human inflammatory breast cancer model. ${ }^{19}$

Clinical tools capable of determining which types of tumors would be expected to benefit from particular therapies are still in development. Our results demonstrate that EZH2 expression is frequent in locally advanced tumors, and suggest that EZH2 presence may not be associated with the response to neoadjuvant treatment with anthracyclines. However, other studies with more patients are needed to confirm this observation.

\section{References}

1 Schwartz GF, Hortobagyi GN, Masood S, Palazzo J, Holland R, Page $\mathrm{D}$; Consensus Conference Committee. Proceedings of the consensus conference on neoadjuvant chemotherapy in carcinoma of the breast, April 26-28, 2003, Philadelphia, PA. Hum Pathol 2004; 35(7):781-784

2 Charfare H, Limongelli S, Purushotham AD. Neoadjuvant chemotherapy in breast cancer. Br J Surg 2005;92(1):14-23

3 Mathew J, Asgeirsson KS, Agrawal A, et al. Neoadjuvant chemotherapy in locally advanced primary breast cancers: the Nottingham experience. Eur J Surg Oncol 2007;33(8):972-976

4 Specht J, Gralow JR. Neoadjuvant chemotherapy for locally advanced breast cancer. Semin Radiat Oncol 2009;19(4):222-228

5 Costa SD, Loibl S, Kaufmann M, et al. Neoadjuvant chemotherapy shows similar response in patients with inflammatory or locally advanced breast cancer when compared with operable breast cancer: a secondary analysis of the GeparTrio trial data. J Clin Oncol 2010;28(1):83-91

6 Liu SV, Melstrom L, Yao K, Russell CA, Sener SF. Neoadjuvant therapy for breast cancer. J Surg Oncol 2010;101(4):283-291

7 Fernández-Sánchez M, Gamboa-Dominguez A, Uribe N, et al. Clinical and pathological predictors of the response to neoadjuvant anthracycline chemotherapy in locally advanced breast cancer. Med Oncol 2006;23(2):171-183

8 Rastogi P, Anderson SJ, Bear HD, et al. Preoperative chemotherapy: updates of National Surgical Adjuvant Breast and Bowel Project Protocols B-18 and B-27. J Clin Oncol 2008;26(5):778-785

9 Caudle AS, Gonzalez-Angulo AM, Hunt KK, et al. Predictors of tumor progression during neoadjuvant chemotherapy in breast cancer. J Clin Oncol 2010;28(11):1821-1828

10 Chase A, Cross NC. Aberrations of EZH2 in cancer. Clin Cancer Res 2011;17(9):2613-2618

11 Gong Y, Huo L, Liu P, et al. Polycomb group protein EZH2 is frequently expressed in inflammatory breast cancer and is predictive of worse clinical outcome. Cancer 2011;117(24): 5476-5484

12 Shen L, Cui J, Liang S, Pang Y, Liu P. Update of research on the role of EZH2 in cancer progression. Onco Targets Ther 2013;6:321-324

13 Chang CJ, Hung MC. The role of EZH2 in tumour progression. Br J Cancer 2012;106(2):243-247

14 Raaphorst FM, Meijer CJ, Fieret E, et al. Poorly differentiated breast carcinoma is associated with increased expression of the human polycomb group EZH2 gene. Neoplasia 2003;5(6): 481-488

15 Bachmann IM, Halvorsen OJ, Collett K, et al. EZH2 expression is associated with high proliferation rate and aggressive tumor subgroups in cutaneous melanoma and cancers of the endometrium, prostate, and breast. J Clin Oncol 2006;24(2):268-273

16 Jiang T, Wang Y, Zhou F, Gao G, Ren S, Zhou C. Prognostic value of high EZH2 expression in patients with different types of cancer: a systematic review with meta-analysis. Oncotarget 2016;7(4): 4584-4597

17 Guo S, Li X, Rohr J, et al. EZH2 overexpression in different immunophenotypes of breast carcinoma and association with clinicopathologic features. Diagn Pathol 2016;11:41

18 Holm K, Grabau D, Lövgren K, et al. Global H3K27 trimethylation and EZH2 abundance in breast tumor subtypes. Mol Oncol 2012; 6(5):494-506 
19 MuZ, Li H, Fernandez SV, Alpaugh KR, Zhang R, Cristofanilli M. EZH2 knockdown suppresses the growth and invasion of human inflammatory breast cancer cells. J Exp Clin Cancer Res 2013;32:70

20 Debeb BG, Gong Y, Atkinson RL, et al. EZH2 expression correlates with locoregional recurrence after radiation in inflammatory breast cancer. J Exp Clin Cancer Res 2014;33:58

21 Hayward JL, Carbone PP, Heusen JC, Kumaoka S, Segaloff A, Rubens RD. Assessment of response to therapy in advanced breast cancer. Br J Cancer 1977;35(3):292-298

22 Fisher B, Brown A, Mamounas E, et al. Effect of preoperative chemotherapy on local-regional disease in women with operable breast cancer: findings from National Surgical Adjuvant Breast and Bowel Project B-18. J Clin Oncol 1997;15(7):2483-2493

23 Fisher B, Bryant J, Wolmark N, et al. Effect of preoperative chemotherapy on the outcome of women with operable breast cancer. J Clin Oncol 1998;16(8):2672-2685
24 Wolmark N, Wang J, Mamounas E, Bryant J, Fisher B. Preoperative chemotherapy in patients with operable breast cancer: nine-year results from National Surgical Adjuvant Breast and Bowel Project B-18. J Natl Cancer Inst Monogr 2001; (30):96-102

25 Collett K, Eide GE, Arnes J, et al. Expression of enhancer of zeste homologue 2 is significantly associated with increased tumor cell proliferation and is a marker of aggressive breast cancer. Clin Cancer Res 2006;12(4):1168-1174

26 Athanassiadou AM, Tsipis A, Patsouris E, et al. Enhancer of zeste homologue 2 expression in breast carcinoma smears in relationship with p53, Ki-67 and other prognostic parameters. Acta Cytol 2011;55(2):180-186

27 Kleer CG, Cao Q, Varambally S, et al. EZH2 is a marker of aggressive breast cancer and promotes neoplastic transformation of breast epithelial cells. Proc Natl Acad Sci U S A 2003;100(20): 11606-11611 